\title{
DERIVATION OF THINNING REGIMES THROUGH USE OF A MODEL FOR BALSAM FIR IN QUEBEC ${ }^{2}$
}

\author{
By P. E. VEZINA ${ }^{2}$
}

\begin{abstract}
A thinning regime was derived through use of a model developed to grow balsam fir (ABIES BALSAMEA (L.) Mill.) trees at any desired size between the limits set by normal and open stand densities. Interpolations were made between the normal number of trees in fully-stocked even-aged balsam fir stands and the number at which crowns of fully open-grown individual balsam fir just close at square spacing. The increase in the number of trees in a fully-stocked balsam fir stand of a given average d.b.h. being little influenced by site was used to establish the basis for the thinning regime. The simple regime prescribes a pre-commercial and two commercial thinnings, and a regeneration cutting when the stand reaches about 7 inches in d.b.h. From comparisons of the amount of growing stock of the hypothetical thinned stands with that of unmanaged fully-stocked stands, it would seem that a managed stand of balsam fir might carry a basal area per acre of 49,58 , and 75 per cent of the unmanaged stands at average d.b.h.'s of 3,5 and 7 inches respectively.
\end{abstract}

\section{RESUME}

On a produit, au moyen d'un modèle forestier, un régime d'éclaircies destiné a faire croître des sapins baumiers à n'importe qu'elle dimension dans les limites fixées par la densité "normale" et celle des arbres de plein découvert. La procédure consiste à interpoler entre le nombre normal de tiges dans les peuplements équiennes complets de sapin et celui qui correspond à des individus de plein découvert dont les cimes se touchent, en supposant un espacement régulier en carré. L'augmentation du nombre de tiges dans un peuplement complet de sapin d'un diamètre moyen donné, qui est peu influencée par la qualité de station, a servi de base au régime d'éclaircies. Ce régime simple propose une éclaircie précommerciale, deux coupes progressives lorsque le peuplement a atteint des diamètres moyens de 3.5 et 5.2 pouces et une coupe de régénération vers 7 pouces. Il semble, à la suite de comparaisons de la densité résiduelle des peuplements hypothétiques écbaircis à celle des peuplements normaux, que des peuplements aménagés de 3,5 , et 7 pouces de diamètre puissent avoir des surfaces terrières à l'acre égales à 49, 58 et 75 pour cent de celles qui caractérisent des peuplements normaux de diamètres moyens équivalents.

\footnotetext{
${ }^{1}$ Department of Forestry, Canada, Forest Research Branch Contribution No. 571.

${ }^{2}$ Research Officer, For. Res. Br., Dept. of Forestry, Box 35, Sillery, P.Q.
} 


\section{INTRODUCTION}

A previous report on crown width-d.b.h. relationship presented equations by means of which the maximum crown area of a balsam fir with a given crown width could be predicted for different diameters (Vézina 1962b). The maximum crown area values allowed the computation of the minimum number of open-grown balsam fir that are theoretically required to produce a complete canopy.

The present paper, using the derived numbers of trees for the opengrown balsam fir and the normal numbers of trees for fully-stocked unmanaged balsam fir stands as starting points, presents a model for thinning regimes in even-aged balsam fir stands. It has the dual purpose of demonstrating how a thinning model can be established with a minimum of single measurement information and at the same time provides a thinning guide which may be employed until more detailed information on optimum densities can be obtained through future experimentation. The paper further provides a guide for the design of a thinning investigation based on maintaining stands at specified levels of numbers of trees, basal area, and average diameter.

\section{THE MODEL}

The model, for which stand density calculations before and after thinning were made, assumed normal unmanaged balsam fir stands with average d.b.h. ranging from one to nine inches, and fully open-grown individual balsam fir of like diameters. It is based on the observation that something less than normal basal area will usually provide the optimum combination of growth and growing stock (Smith et al. 1961, p. 42).

The data for the normal even-aged balsam fir stands are based on 77 temporary sample plots, 0.1 or 0.2 acre in area, most of them established in the Laurentide Park, Quebec, and in adjacent areas on two site-types: the Dryopteris-Oxalis (D-O type, 26 plots) and the Hylocomium-Oxalis (H-O type, 51 plots) site-types (Linteau 1955). The individual tree measurements were taken on 53 open-grown balsam fir in the same areas (see Vézina 1962b).

A single variable, that is, the average stand diameter, was used to replace both age and site index for determining the residual numbers of trees after thinning. The advantage of this approach is that average d.b.h. can be more easily measured, or estimated, than either site index or age, which are eliminated from the computations.

Density before and after thinning was expressed in terms of number of stems per acre. The amount of competition at the start and end of each thinning interval is therefore indicated by comparing the total number of trees per acre in the thinned hypothetical stands with that of normal, unthinned stands of like average diameter. It is assumed that when the average diameter of the thinned stand reaches a value which corresponds to that of a stand with a normal number of trees, competition will be sufficient to reduce rate of growth of individual trees which at the same time calls for another thinning. It is further assumed that no suppression mortality will occur due to repeated thinnings. The degree to which the number of trees of a stand has to be reduced by thinning is determined by the difference 
in numbers of trees between the normal density and the desired density for any given average d.b.h. Such a procedure should lower the stand density enough to allow a substantial growth of the residual trees until the next thinning.

The Thinning Rule

A number of methods used for gauging the degree of release provided by thinning have been listed by Lemmon and Schumacher (1963), and some of these and others have been described in details by Vézina (1963b). The thinning rule used here provides for a specified number of residual trees per acre ${ }^{3}$.

It is assumed that the distribution of residual trees about their average diameter will be normal, with a range in d.b.h. similar to that found in fully-stocked balsam fir stands of like average diameter. In fact, the tree diameter class distributions that are involved in fully-stocked balsam fir stands are little known. Quite often, skewed distributions are encountered. Yet it seems that the spacing pattern of trees should influence growth. It is conceivable that stands with more variable tree diameters could have a relatively less uniform spacing with more trees in clumps (Smith et al. 1961). Conversely, in managed stands, competition is held at a minimum, and variation in growth between trees would result mainly from genetic and crown class differences between trees and from differences in microsite (Staebler 1960). Several measures of distribution about an average spacing could be used to assess objectively the uniformity in the distribution of trees. One of these, the standard deviation of tree diameters, was used by Buckman (1962) in the prediction of basal area growth. Another one, the ratio of largest to average d.b.h., was used by Smith and Ker (1960) in British Columbia. The more uniform the distribution of trees, the smaller the standard deviation or the ratio. The latter measure of distribution was used in the study.

RESULTS

Influence of site on the per cent number of trees in a given diameter group for a given average stand d.b.h.

As the plots being located in two different site-types, it was important to determine the influence of site on the per cent number of trees in a given diameter group for a given average stand d.b.h. Data presented in Figure 1 show only about 5 to 10 per cent more trees in the 1 - to 3 -inch diameter group in the D-O type than in the H-O type at the same average d.b.h. In the other three diameter groups, the per cent numbers of trees are very similar for both site-types at the same average d.b.h. It was therefore concluded that in fully-stocked balsam fir stands of a given average diameter the number of trees per acre in each diameter group is similar regardless of site. That stands of the same average d.b.h. are more nearly alike with respect to the number of trees per acre than those of the same age and site index has been shown by other workers for Douglas fir, and western hemlock (Smith et al. 1961, p. 38).

\footnotetext{
${ }^{3} 0.6$ inch and up at d.b.h., provided they are of the same age as the dominant stems. Advanced growth excluded.
} 


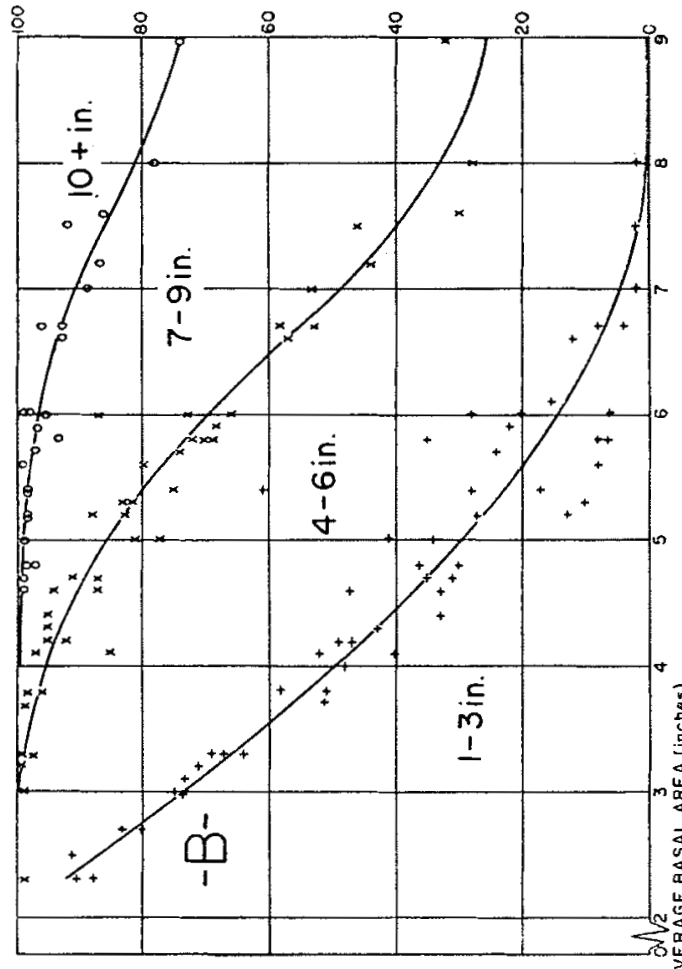

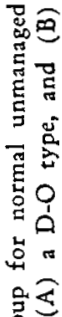

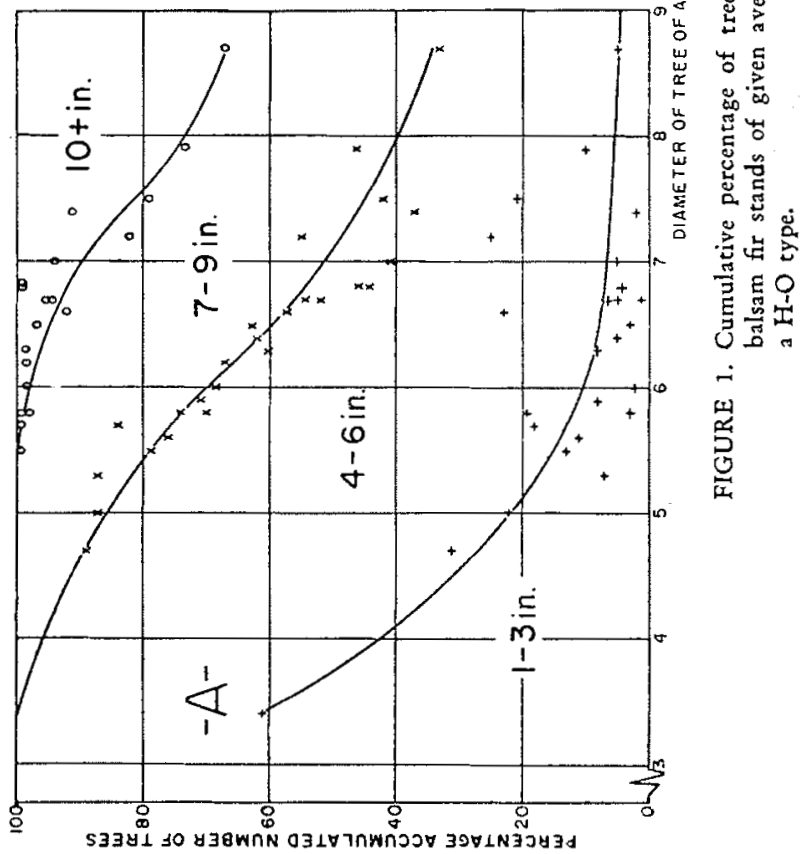


Distribution of trees about an average spacing

The ratio of largest to average d.b.h. has been calculated for each of the 77 plots. It was found that in fully-stocked balsam fir stands the most vigorous trees will attain about twice the average stand d.b.h., and further that the ratio decreases as the stand d.b.h. increases (Table 1). Since the d.b.h. of the plots are closely related to their ages, this means that as the stands grow older, the spacing becomes more regular and, as a result, the opportunity for uniformity in growth of individual trees is better. It should be emphasized here that a ratio even smaller than 1.7 would be obtained in balsam fir stands in which spacing would have been regulated at an early age.

TABLE 1

LARGEST D.B.H. ATTAINED BY THE MOST VIGOROUS TREES, AND RATIO OF LARGEST TO AVERAGE D.B.H. IN DENSE NATURAL BALSAM FIR STANDS

OF A GIVEN AVERAGE DIAMETER

\begin{tabular}{cccc}
\hline $\begin{array}{c}\text { Average } \\
\text { d.b.h. }\end{array}$ & $\begin{array}{c}\text { Largest } \\
\text { d.b.h. }\end{array}$ & $\begin{array}{c}\text { Ratio of Iargest } \\
\text { to average d.b.h. }\end{array}$ & $\begin{array}{c}\text { No. } \\
\text { plots }\end{array}$ \\
\hline 2 & 4.7 & 2.35 & 2 \\
3 & 6.4 & 2.13 & 9 \\
4 & 8.5 & 2.12 & 10 \\
5 & 9.9 & 1.98 & 18 \\
6 & 10.7 & 1.78 & 21 \\
7 & 12.2 & 1.74 & 13 \\
\hline
\end{tabular}

Number of trees in open and normal stands

In numerical thinning schedules, spacing is regulated by specifying the most desirable number of trees to be reserved. Determining optimum schedules, however, requires much study and, in the absence of any practical schedule for balsam fir, it is important to know within what limits the density as expressed by the number of trees can be varied while the whole area is kept occupied with tree crowns (Smith et al. 1961).

It is already known (Smith and Ker 1960, Krajicek et al. 1961, Vézina $1962 \mathrm{~b}, 1963 \mathrm{a})$ that by determining the crown width-d.b.h. relationship in fully open-grown trees, an estimate can be made of the number of open-grown trees of a given d.b.h. necessary to cover an acre fully. Assuming that crown width corresponds with square spacing, minimum numbers of opengrown balsam fir required to fully cover an acre have been calculated, and are illustrated in Figure 2 (see also Vézina 1962b). An estimate of the number of trees in normal unmanaged balsam fir stands, based on the data analyzed in this study, is also included in Figure 2 . It is shown that stand density can be varied within wide limits to provide desired tree sizes and growth rates.

\section{The thinning regime}

The thinning regime proposed here is based on interpolations made between the normal number of trees in fully-stocked balsam fir stands and the 


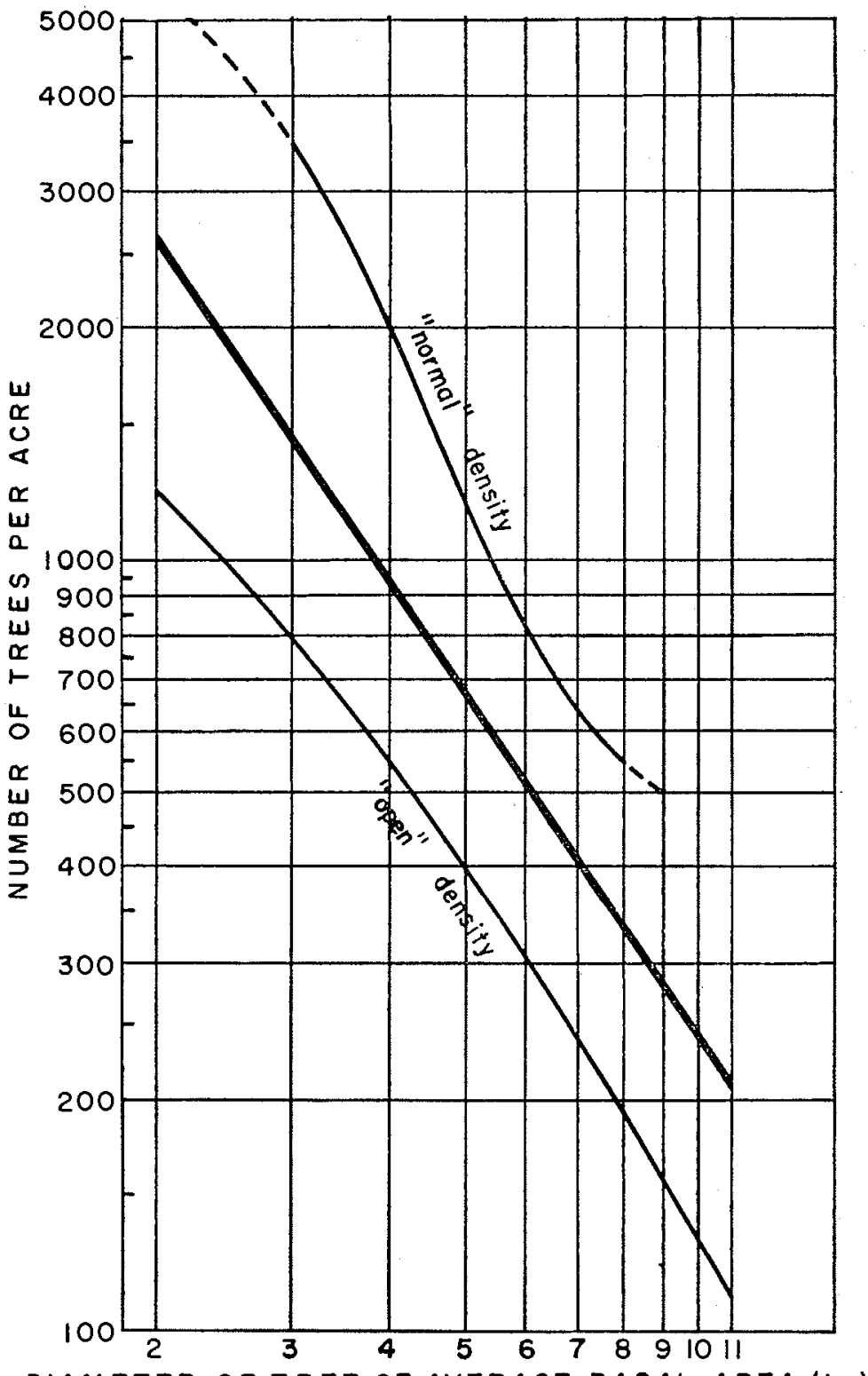

DIAMETER OF TREE OF AVERAGE BASAL AREA ( $\mid n$.

FIGURE 2. Calculated minimum numbers of open-grown balsam fir required to cover an acre fully, nomal numbers of trees in unmanaged balsam fir stands, and the proposed regime (heavy line) based on interpolations between the "open" and "normal" stand densities. 
number at which crowns of fully open-grown individual balsam fir just close at square spacing. As a matter of fact, the balsam fir trees can grow to any desired size between the limits set by the normal density line and one at the approximate mid-point between it and the open density line (figure 2). It would not be wise, indeed, to grow balsam fir stands at very wide spacings since competition from less valuable hardwoods and shrubs would be too severe, especially on the better sites.

It should be pointed out that the location of the optimum density line is somewhat subjective. Theoretically this line should be placed as close as possible to the open density line provided that gross increment is not lost due to failure of the trees to fully occupy the site. Other factors such as invasion of undesirable species may, of course, necessitate maintaining the optimum line at a higher level. Generally speaking, one would expect that the optimum line should not be parallel to the open density but should gradually approach the maximum density line at the highest average diameters or upon approach to rotation age. One further factor may affect the placement of the optimum density line for species in which sawtimber production is of maximum importance; it may be desirable to sacrifice some gross increment per acre to achieve maximum dollar values through the production of trees of maximum diameters in a relatively short time such as in sawtimber production.

The largest d.b.h. corresponding to a given average stand diameter for the fully-stocked stands was made equal to three times the standard deviation. Knowing the total number of trees desired at a given average stand d.b.h., and assuming a normal distribution, the theoretical number of trees in each diameter class was calculated corresponding to the total number of trees at the start and end of each thinning interval. Corresponding basal areas, in square feet per acre, at the start and end of each thinning interval, were then calculated for the thinned stand. These relationships, together with the basal area values for normal unmanaged balsam fir stands and the calculated residual densities by number of trees for the thinned stands of given average diameter are given in Figure 3.

\section{Discussion}

It should be realized that fully-stocked unmanaged balsam fir stands do not provide the optimum combination of growth and growing stock. They generally contain, at all ages, too many trees per acre of too small an average d.b.h. Most of the dense balsam fir stands growing on good sites in accessible areas could be thinned at an early age according to practical schedules in order to increase their growth rate without reducing significantly the area occupied with crowns. The feasibility of such a cutting practice was shown by Matte (1962) for balsam fir stands growing in the Epaule River watershed near Quebec City. This reduction in density would be most welcome from the regeneration standpoint, by increasing the amount of light beneath dense fir canopies, which is believed to be often critical for the early growth of established fir seedling crops (Vézina 1962a).

It should be pointed out that with a given intensity of thinning as measured in terms of residual basal area, various sizes of trees can be 


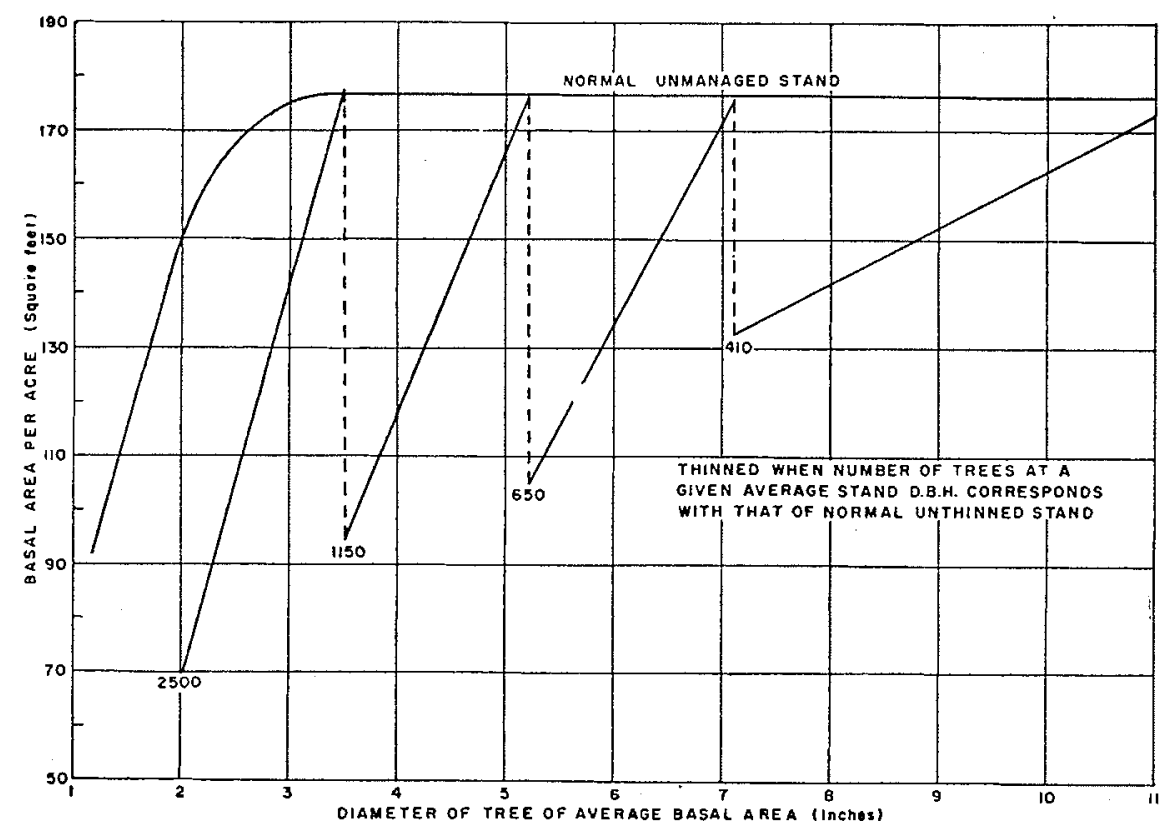

FIGURE 3. Basal area-average d.b.h. relationships for balsam fir stands in Quebec. Comparisons are shown between hypothetical stands thinned by use of the interpolation method between "open" and "normal" stand densities, and unthinned stands. Solid lines for the thinned stands represent basal area increase due to growth. Broken lines represent reduction in basal area due to thinning. Figures indicate the calculated residual densities by number of trees.

removed in thinning which will alter the average diameter immediately before and after thinning in different ways depending on the sizes of trees removed. In Figure 3 vertical lines have been used to indicate material removed in thinning, implying no change in average diameter before and after thinning. If the stand had been thinned by the German method, removing suppressed and intermediate trees, there would be an increase in average diameter after thinning, resulting in a line sloping to the right, whereas if a crop tree release had taken place tending to remove larger competing trees from around crop trees the line would tend to move to the left indicating a slight reduction in average diameter. French thinning, removing competing dominants and reserving co-dominants for crop trees would conversely decrease the average diameter even further and make the thinning line move to the left. The use of the vertical line to indicate thinnings results from the fact that average diameter has been substituted for age and site, therefore implying no change in the diameter of the stand at the time of thinning.

It will be noted that the upper limit curve in Figures 2 and 3 represents the number of trees average diameter relationship and the basal area relationship for unmanaged normal density fully stocked stands. These are stands 
sufficiently stocked that natural mortality is taking place and that the stands are held at the carrying capacity of the sites concerned. In effect, the fully stocked basal area line is not a smooth straight line but is a sawtoothed line showing periodic mortality in the stands of full stocking. Studies in other species including lodgepole pine, and red and white pine (Smithers $1954,1961)$ indicate that natural mortality begins to become a factor in the stand when density exceeds approximately 85 per cent of the fully stocked basal area for the site. In Figure 3, however, the thinned stands have been permitted to increase until they achieve the basal area of normal unmanaged stands. It is probable that before having reached this level, natural mortality would have taken place and as a consequence some increment would be lost. Consequently it might be desirable to keep thinned stands below this level so that natural mortality will not take place in the thinned stand.

Ideally, the thinning grade should be determined on the basis of growth rate, and thinning frequency. It is nevertheless proposed that the analytical system presented here offers a reasonable basis for the simple thinning systems applied to balsam fir stands in some areas in Quebec. It should provide a guide to the orderly reduction in number of trees as stand diameter increases. It should be kept in mind, however, that such a scheme, based on interpolations between open and normal stand densities, does not provide for the most desirable regime from silvical and economic viewpoints. As was stated by Staebler (1960), "a thinning schedule could hardly be derived mathematically without extreme simplification through use of model of some sort". It should be eventually supplemented by other, more conventional schedules.

The distribution about an average spacing observed in the fully-stocked unmanaged balsam fir stands analyzed, was applied by means of the ratio of largest to average d.b.h. to the thinned hypothetical stands, although in practice the latter will have a better uniformity in spacing due to thinning and, as a result, less variable stem diameters.

There exists no evidence regarding desirable levels of growing stock for balsam fir. From comparisons of the amount of growing stock of the hypothetical thinned stands to that of unmanaged fully-stocked stands, it would seem that a managed stand of balsam fir might carry a basal area per acre of 49,58 , and 75 per cent of the unmanaged stands at average d.b.h.'s of 3, 5, and 7 inches respectively. These levels of residual basal area appear to be suitable in terms of the probable capacity of the stand to achieve full increment per acre at reduced densities. The differences in level, i.e. lower residual levels at younger ages are also consistent with the findings in red pine-white pine stands and in lodgepole pine stands (Smithers 1954, 1961).

Figure 3 makes up the prescribed thinning regime. It shows the d.b.h.'s at which the stand is to be thinned, and the number of trees to be left after each thinning. From what is known of the rate of growth of balsam fir growing in fully-stocked stands it is estimated that the regime prescribed in Figure 3 will correspond to thinning intervals of about 20-25 years for the H-O type, and about 15-20 years for the D-O type. The prescribed thinning regime, however, will lengthen the thinning intervals with age to 
follow the normally declining rate of diameter growth over a rotation. It should be well suited to most situations, but other intervals and intensities of thinning, about which the decision is largely economic, might have to be determined from the relationship presented in Figure 2.

The results of this study should be applicable to balsam fir stands of the B.1a Section of the Boreal Forest Region (Rowe 1959). They cannot be generalized so as to include other forest regions, since comparisons of balsam fir stands in the Great Lakes - St. Lawrence and Acadian Regions ${ }^{4}$ have indicated that fir does not behave the same way in the three regions, being apparently much more "tolerant" as one moves to the north. This causes considerable changes in the distribution of stems per diameter, and the amount of basal area which can be crowded into an acre of a given site.

\section{REFERENCES}

BUCKMAN, R. E. 1962. Growth and yield of red pine in Minnesota, U.S. D.A., Forest Service, Tech. Bull. No. 1272.50 pp.

KRAJICEK, J. E. et al. 1961. Crown competition-a measure of density. For. Sci. 7:35-42.

LEMMON, P. E., and F. X. SCHUMACHER. 1963. Theoretical growth and yield of hypothetical ponderosa pine stands under different thinning regimes. For. Sci. 9:33-43.

LINTEAU, A. 1955. Forest site classification of the northeastern coniferous section, boreal forest region, Quebec. Canada Dept. of Northern Aftairs and National Resources, Forestry Branch Bull. No. 118.85 pp.

MATTE, F. 1962. The first ten years of the Epaule project. Pulp Paper Mag. Can., Woodlands Review Section, Index No. 2128 (F-2): 1-6.

ROWE, J. S. 1959. Forest Regions of Canada. Canada Dept. of Northern Affairs and National Resources Forestry Branch Bull. No. 123.71 pp.

SMITH, J. H. G., and J. W. KER. 1960. Growing Douglas fir and western hemlock trees at desired rates. Univ. of B.C., Faculty of Forestry, Res. Note No. 24. 6 pp.

SMITH, J. H. G. et al. 1961. Economics of reforestation of Douglas fir, western hemlock and western red cedar in the Vancouver forest district. The Univ. of B.C., Faculty of Forestry, For. Bull. No. 3. 144 pp.

SMITHERS, L. A. 1954. Thinning in red and white pine stands at Petawawa Forest Experiment Station. Canada Dept. of Northern Affairs and National Resources, Forestry Branch, Silv. Res. Note No. 105. 52 pp.

SMITHERS, L. A. 1961. Lodgepole pine in Alberta. Canada Dept. of Forestry, For. Res. Br., Bull. No. 127. 153 pp.

STAEBLER, G. R. 1960. Theoretical derivation of numerical thinning schedules for Douglasfir. For. Sci. 6:98 109.

VEZINA, P. E. 1962a. Recherches récentes concernant le traitement des sapinières de Québec. Schweiz. Z. Forsew. 113: 727-732.

VÉZINA, P. E. 1962b. Crown width-d.b.h. relationship for open-grown balsam fir and white spruce in Quebec. For Chron. 38: 463-473.

VEZINA, P. E. 1963a. More about the crown competition factor. For. Chron, 39:313-17.

VÉZINA, P. E. 1963b. Objective measures of thinning grades and methods. For. Chron. 39: 290-300.

- Personal communication from G. Baskerville, Research Officer at Fredericton, N.B. March $18,1963$. 